\title{
A Cloud of Vapour, the Cool of the Cellar: the Horror Genre in Latvian Literature
}

\author{
BĀRBALA SIMSONE
}

\begin{abstract}
The paper gives an insight into the horror fiction genre in Latvian literature, from folklore to modern literary works. Although the horror genre is represented by only a few works in Latvian literature, these works manifest several national characteristics. These characteristics are the main focus of the present study. Although Latvian folklore offers plenty of material for the horror genre, in the form of ghost stories and legends, very few writers have actually exploited these rich sources in their creative work. The first attempts to incorporate horror motifs into original literary works appear only at the beginning of the $20^{\text {th }}$ century and, surprisingly, they are found in poetry rather than prose. The first elements of the horror genre in drama appeared in a play by Jānis Rainis. Prose was the last literary form where elements of horror fiction appeared. Short story writers first used elements of legend and folklore in a symbolic and allegorical manner, and only as late as the 1920s did they start to incorporate the supernatural without explaining it away rationally. Under the Soviet regime development of the horror genre stopped altogether, since it was unacceptable to the ruling system. The next traces of the horror genre began to appear in Latvian literature only in the 1970s and 1980s. New horizons opened when national independence was regained in 1990.
\end{abstract}

Keywords: genre characteristics, horror fiction, Latvian literature, poetry, short story

Considering the relatively short history of Latvian literature as such, Latvian genre literature seems like a granddaughter in relation to its European grandmother, and horror literature seems ludicrously young, even in the context of Latvian genre literature. To date only a handful of Latvian authors have turned to writing horror stories and novels, and their contribution in this field has been quite limited. In his afterword to the collection of stories Visu rožu roze (Rose of Roses), published in 1987, Andris Jakubāns seeks to explain the absence of this genre in Latvian literature: "It may well be that Latvian writers have made virtually no use of this poetics of ghosts and stories as a source of inspiration because many periods in our people's history have been so grim, so marked by slavery - not only of the legally constituted, but also of

DOI: http://dx.doi.org/10.12697/IL.2014.19.2.5 
the spiritual kind - that the author simply wasn't capable of writing anything of that kind. Lyricism is so triumphant in all of Latvian literature, and conflict mainly has a moral and ethnic character, because one has to be very strong to look at oneself in situations even more terrifying than real life." (Jakubāns 1987: 186) It is difficult to say whether this is indeed the true reason, because the horror genre does exist among other peoples with a similar history.

Ghost stories and stories of terrifying occurrences, abundant in the folklore of other peoples, may also be found in the Latvian oral heritage, mainly in the form of legends. In most cases they are stories concerning the unfortunate demise of a certain individual, followed by the haunting of a particular location (e.g., different versions of the legend of the Green Lady of Dundaga Castle, the bloodstain on the wall of a chamber in Ėdole Castle, the evil Baron Von der Recke of Jaunpils etc.). However, since most of these legends relate to specific settlements and buildings, they may be regarded as relatively young, and the horror elements are usually not particularly detailed, placing more emphasis on the moral aspect. For example, the maiden of Dundaga Castle is punished for her curiosity, spying on the dwarves' wedding through the keyhole, but there is no description of the appearance of the maiden when she roamed the castle after death or why she was to be feared. There are also stories about apparitions of the dead (vel̦u māžošanās), guardians of hidden treasure, werewolves, witches, the strangler demon lietuvenns, the 'black book' used to summon the dead, etc.

Even though there are few horror motifs in this stratum of folklore, it would indeed constitute a useful resource for writers, but few have so far applied it. Such ghost stories appear only as legends once heard and retold in full or partially in the stories based on childhood memories by classic Latvian authors: Baltā grāmata (The White Book) by Jānis Jaunsudrabiňš (1927) and the cycle Dievs, daba, darbs (God, Nature, Work) by Anna Brigadere (19261933). The writers recall the "old wives' tales" they once heard as children by the light of a splint: "But when the telling has turned to horrific occurrences, it can go on and on. One person knows of robbers living in lonely huts in the depth of the forest, who search out farms where there happen to be few men present; another knows of ghosts waiting at the crossroads near a cemetery or other mysterious places, a third knows of terrifying spirits of the dead who can find no rest, having spent their lives in evildoing." (Brigadere 1997: 177)

The oldest motifs in Latvian original literature that we might classify as belonging indisputably to the genre of horror appear only at the beginning of the $20^{\text {th }}$ century, and are initially found in poetry rather than prose. These are the ballads "Baigi” (“The Apparitions”, 1903) and "Rēgi” (“The Ghosts”, 1908). As 
A Cloud of Vapour, the Cool of the Cellar: the Horror Genre in Latvian Literature

described by literary critic Guntis Berelis in his History of Latvian Literature, ${ }^{1}$ "these are nocturnal visions or apparitions (possibly inspired by Edgar Poe's The Raven), in which, it seems, Latvian literature for the first time encounters imaginings and nightmarish images from the spheres beyond consciousness". (Berelis 1999: 44) On dark nights, Plūdonis' lyrical protagonists are visited by horrifying figures: the Devil himself (in the ballad "The Ghosts") or a demon of the night (in the ballad "The Apparitions"), which seek to stifle his joy of living and suffocate his soul through incomprehensible, gloomy visions. The influence of the poetry of the American horror classic Edgar Allan Poe really can be discerned in the rhythm and the structure of the plot, where an atmosphere of fear develops gradually and inevitably, while the nameless narrator can only submit blindly to the course of events. Elements of horror can also be observed in Plūdonis' ballads "Jumis - atriebèjs" ("Jumis the avenger") and "Salgales Mada loms" ("Salgales Madis' catch", 1913), where the suspense of the plot is increased masterfully, culminating in a mystical and horrifying dénouement.

Elements of horror appear in drama for the first and so far the only time in Rainis' play Spè ēju, dancoju (I played and I danced, 1915). The play is traditionally explained in symbolic terms, but at least in a broader sense it can be seen as an interpretation of the ancient vampire myth: the main antagonist is the deceased Lord, who, rather than sleep peacefully in his coffin, rises up to suck the blood of the living; in order to bring back to life a victim of the Lord - the maiden Lelde - the musician Tots must descend into a vividly depicted kingdom of devils and other evil spirits, and outdo them in cunning. The atmosphere of horror is created not so much through the characters' text, but through the detailed stage directions inserted by the poet, especially in the cemetery scenes described in Act 2: "A light dust rises from the graves and paths, and rolls towards Tots, ascending. Arms and legs stretch out towards him from the graves; torn and scattered limbs appear in the uncertain light. [...] One of the dead rushes from the cemetery and darts past, followed by several others; graves begin to open; the dead raise their heads; moans are heard." (Rainis 1950: 341) The text of the play might be full of symbolism, echoing the rhythms of folklore, but the setting is unmistakably Gothic.

\footnotetext{
Neither has there been much discussion of the horror genre, either in the form of translated or original literature, in Latvian literary criticism. One of the most active critics of the horror genre is Guntis Berelis, and so this paper cites several of his analytical articles on works by authors writing in this genre.
} 
The period of the 1920s and 30s might in a sense be termed the early period of Latvian horror literature. Elements of this genre that have a specific role first appear in prose in the stories of Augusts Saulietis: "Velu tiesa" "Trial of the Spirits", 1925), "Ģindenis" (“The Skeleton”), "Ragana" ("The Witch") etc., in which the traditional, realistic storyline is interrupted by inexplicable and incomprehensible phenomena from the world beyond the grave. For example, in the story "Neaizberamã aka" ("The well that cannot be filled", 1927) the main character, Ličcu Dāvis, is tormented by the spirit of his dead neighbour, whose bride Dāvis has stolen many years ago; the ghost is not the immediate cause of Dāvis' death, but its presence and active role in the story is undeniable, so that it must be interpreted as more than just a dream, a vision or a symbol. Here it should be added that figures representing the Devil, spirits of the dead and demons do occur earlier in Latvian prose, but the presence of a supernatural being in itself does not classify a work as belonging to the genre of horror, because such figures can also be interpreted in a symbolic, allegorical or even psychological sense (as is often the case with the demons referred to by the Decadents), or else they can be folkloristic or mythical, not being at all frightening (as with the devils in the novella Don-Žuana pēdèjā mìlestîba (The Last Love of Don Juan, 1922) by Jānis Akuraters or in the novel Jaunsaimnieks un velns (The New Farmer and the Devil, 1933) by Jānis Jaunsudrabiñš).

The influence of the horror classic Edgar Allan Poe is observable in works by several masters of Latvian short prose from this period, such as Jānis Ezeriñ̌ and Kārlis Zariņšs, but this influence does not always relate to the elements of horror and mystery; more commonly it appears in the melancholic, selfanalytical mood, the inner tension of the story and the form of expression. However, Ezeriņš story "Joču pirts" ("Joči Bath-House", 1923), along with Zarinş̌̀ "Mūžiba" ("Eternity", 1927) and "Piemini nāvi, Heidenkranc!" ("Remember that you will die, Heidenkranc!", 1927) were influenced quite perceptibly by Poe's stories "The Black Cat" (1843) and "The Facts in the Case of Mr Waldemar" (1845). "Joči Bath-House" is a seemingly traditional story about rural life and love in the 'style of itinerant farmhands', but the climax of the story develops from a fateful coincidence: an accident caused by a black cat, resulting in the death of the child of maidservant leva and her own descent into madness. The motto of Zarin šs" story "Remember You Will Die, Heidenkranc!" is based on a quote from Poe's story "The Pit and the Pendulum" (1842): "An outstretched arm caught my own as I fell fainting into the abyss," (Zarinš 2000 : 131) and the whole story is pervaded by an atmosphere of inescapable death that is characteristic of the works of the horror classic, even though the hero's suffering and fear, when hanging by the edge of his coat at the top of a threehundred-metre tower, results not from some kind of supernatural intervention, 
but simply from the cruelty of his fellow human beings, just as in Poe's story. The stories by Mirdza Bendrupe commonly also include mystical motifs. For example, the story "Helēna" (1939) is based on the popular urban legend concerning a beautiful woman met in the cemetery, about which the enamoured protagonist subsequently learns that she has died ten years previously. In general, however, Latvian short prose of this period (and later), although full of mystical moods, fatalism, foreboding and unmotivated fear, rarely goes as far as to include truly horrific images that are not explained in terms of references to reality, such as dreams, symbols or the protagonists' changing state of mind.

Elements of horror obtain a fully-developed, independent role not only in short prose, but also in epic literature, through the works of Aleksandrs Grins, who presents authentic horror through a combination of mystical themes and historically-based scenes of cruelty. Grins is attracted by the figure of the witch, the torture chambers of the inquisition (often with detailed accounts of torture methods), spirits and ghosts of the dead. Grins never consciously set out to write a horror novel or a volume of horror stories, but these elements do have a significant role in his novels Nameja gredzens (The Ring of Namejs, 1932) and Dvēsel̦ putenis (The Storm of Souls, 1933-1934), and especially in his volumes of short stories. In the story "Nameja atgriešanās" ("The Return of Namejs", 1921) the dead chieftain Namejs visits the crusaders, bringing the black death, and the curse is lifted only through Christian ritual and the burning of the chieftain's body. The character of Namejs might be seen in this case as playing a kind of vampire role. In the story "Klaucānu brīvzemnieka testaments" ("The Will of the Free Peasant of Klaucāni”) a peasant marries the daughter of a witch, who goes off one night to join the witches; following his wife, the husband becomes witness to a colourfully described witches' sabbath. In the story "Septin,i un viens" ("Seven and One", 1926) a reckless student in Tartu requests the aid of the Devil himself in a duel, and, as a Faust-like figure of his time, receives assistance for the price of his soul. Heroes often encounter witches, spirits of the dead, succubi, riders of the plague etc., which are partly folkloristic and partly horror figures. In the story "Klusie cieminin" ("Silent Guests", 1935) the spirit of a fallen Latvian rifleman visits his comrades-inarms, although he does not instil horror, only respect. (A similar figure may be found in Aleksandrs Čaks' long poem Mūžîbas skartie (Marked by Eternity, 1940)). These stories, overflowing with passion, often include as elements of horror quite modern, medical factors, such as venereal disease and its outward signs, often physically repulsive.

Grins succeeds admirably in creating an oppressive atmosphere of terror by means of stylistically eloquent description, where practically every detail is intended to heighten the suspense: 
That evening we brothers came together in the large convent hall, which was more brightly lit than all the other rooms of the castle and on other occasions attracted us by its murals and columns, slender and white as young birches. But now a heavy weight pressed down on the breast of each one, so that it was hard to breathe, the blood coursed rapidly in our temples, our ears drummed and hummed, and a faint mist shimmered before our eyes. The faces seemed bloated and lifeless, rendered cadaverous by the strange, dull red glow that flowed in through the windows and doors, seeming to envelop us all in a bloodsoaked shroud, stained with pus and deathly sweat. (Grīns 1990: 10)2

These stories skilfully apply one of the chief principles of the horror genre: even before revealing anything truly frightening, a characteristic set of emotions is instilled in the reader.

Unfortunately, however, following these works, which demonstrate that the horror genre had taken on a life of its own in Latvian literature, too, its development was artificially halted for a long time.

Under the Soviet regime horror was disparaged as a base genre, corrupting people's aesthetic tastes. Moreover, in the frame of Socialist Realism it had no hope of developing anyway: the supernatural aspect of horror would have stood too close to religion and other categories of 'idealistic delusion'. On the other hand, the presence of horror that had a natural, human explanation would have required actions by a sadist or madman, but neither of these could exist under the idealised Soviet regime. Accordingly, for several decades there was a complete vacuum in the genre of horror, as in the genre of literary fantasy.

The next phase of development of original horror literature commenced only in the 1970s and 80s with stories by Vladimirs Kaijaks which critics do not hesitate to label 'Modern Gothic'. Guntis Berelis writes:

The finest of Kaijaks' prose exhibits the specific poetry of horror, where the text is based on a terrifying, supernatural or maybe just elegantly paradoxical metaphor. In some cases there is truly apocalyptic terror, while in other cases it is quite individualised: a person's fear of their own shadow. Certainly, all the motifs utilised by Kaijaks are very contemporary." (Berelis 1999: 214)

The collections of stories Akācija akmens pagalmā (The Acacia in the Stone Courtyard, 1973) and Visu rožu roze (Rose of Roses, 1987) really do provide a typical manifestation of the realities and fears of the age.

\footnotetext{
2 Translations from Latvian by Valdis Bērziṇš.
} 
A Cloud of Vapour, the Cool of the Cellar: the Horror Genre in Latvian Literature

The title story in the volume Rose of Roses is a real gem in the genre of the miniature apocalypse, so that we may draw parallels with the figure of Frankenstein as an inventor incapable of controlling his invention and with the motif of Lucifer's conceit (where a gardener wishes to create "a new origin for a new beginning, a new cycle, a new succession of roses” (Kaijaks 1987: 31), striving in a sense to play God), as well as with achievements in science and the arts. Thus, Andris Jakubāns in his afterword to the volume, and likewise Jūlija Dibovska in her essay (Dibovska 2008) compare the image of the overly vigorous rose with an atomic bomb:

The comparison of the rose with an atomic bomb is a very successful one, in spite of the mild, naive sense of paranoia that accompanies every premonition of the approaching apocalypse. Here we also see the spirit of scientific experimentation of the new century, striving for discoveries, improvements and transformations. A very appropriate slogan for modern industrialism is the idea voiced by the main protagonist, the gardener, that all that has gone before must be destroyed in order to create something new. (Ib.)

A mythical interpretation of the story might also be offered: the rose represents the continually reborn goddess of vegetation, which demands and indeed receives offerings, including human sacrifices. Thus, it is only logical that in the end the creation destroys its creator: the unimaginable vigour of the newly developed rose literally consumes the rest of the garden and the house, and, in some effectively described episodes, deprives the gardener of his sanity and almost takes his very life.

A second story employing horror elements in this volume is "Zirneklis" ("The Spider"), describing how a classic monster gradually draws near its victim, instilling a sense of unease in the reader, too:

The Spider had never seen so much white, sweet flesh before. It trembled with desire, its jaws clamped together, its fangs swelled and it seemed to grow, becoming larger, stronger and more dangerous. It longed to touch this flesh, to feel the pulsating life between its jaws and legs, to cling to it and to suck it dry. (Kaijaks 1987: 95)

Of course, the story might be interpreted in symbolic terms, but the system of imagery employed is sufficiently vivid to create the desired effect. Also outstanding in this genre is the story "Mašina" ("The Machine") in the volume Vecis (The Old Man, 1992): a voice-operated, futuristic car becomes enamoured with its driver and almost kills a real woman out of jealousy, 
but in the end commits suicide in the name of love. The volume The Acacia in the Stone Courtyard contains the story "Mēmais" ("The mute"), where an inexplicable occurrence - an ordinary person losing their power of speech for no apparent reason - is seemingly brought on by the presence of a black cat: "The cat meowed diabolically and gazed at me with bright green eyes". (Kaijaks 1973: 17) One need not look closely to find parallels with Edgar Allan Poe's classic story. In later works by Kaijaks elements of horror appear occasionally (e.g. in the novel Enijas bize (Enija's Braid, 1999) the braid of a woman who has presumably committed suicide seems to strangle the man responsible for her death in his nightmares).

Also in this period Vizma Belševica wrote a comic horror story about a theatre ghost under the title "Baltā sieva" ("The White Lady") (published in 1979 in the volume Nelaime mājās (A Plague at Home)), but the figure of the young suicide, who becomes a theatre buff after death, lives in the dressing room and falls in love with the lead actor, is too amusing and likeable to be frightening.

Among horror novels from this period we should mention Ragana (The Witch, 1981) by Jānis Maulinšs, which is at once characteristic of the time, namely being precise, down-to-earth and full of scientific detail, but at the same time is uncharacteristic in that it projects into the present day, without any rational explanation, a folklore legend concerning a line of witches: women whose husbands in all generations always die soon after the wedding. Mauliņš describes a young scientist who has learned of this phenomenon in a remote area of rural Latvia and seeks to investigate it, but falls under the spell of the youngest witch and the curse (although he escapes death at the last moment). The long and detailed description of how doctors, chemists and biologists, applying the latest techniques, seek to establish the cause of the mysterious deaths never leads to a resolution of the problem; thus, The Witch becomes an interesting exception in the literary logicality of the age, and at the same time fits perfectly into the spectrum of supernatural horror literature.

An unusual form in which to relate a terrifying story was discovered by Dagnija Zigmonte in her work Gausiggais Nazis (The Thrifty Knife, 1988) - a collection of literary adaptations of legends from the northern part of the Kurzeme region, in which she creates masterful pictures through language, endowing elements of folklore - ghosts, spirits of the dead who visit the living and the mythical 'black book' - with a credible form of existence, so that they lose their folkloristic 'once upon a time' quality and instead obtain a very specific definition in the 'here and now', which gives the desired effect. Particularly impressive is the title story: the miserly head of the Veckuški farmstead, in order to save on the food eaten by his labourers, purposefully 
presents his cowherd Gusts with a magical 'thrifty knife', which cuts only the thinnest slices of bread and literally starves the boy to death. The supernatural factor is hardly mentioned at all in the story, but it is precisely this restraint that substantiates its presence and instils fear.

The tendency of incorporating elements of horror into texts in various genres continued after independence was regained, a time when works of very dubitable quality found their way to the publishers. Unfortunately, in many cases it is not the plot that horrifies, but the quality of the work itself. Works to which both conditions apply include Andris Puriņš novel Ar skatienu augšup jeb Vampiru sazverrestîba (Looking Upwards, or the Vampire Conspiracy, 1992). The element of horror obtains such a grotesque form in this work as to border on the absurd: giant bats with the heads of diehard communists fly over fields in a remote district of Latvia and enter at night via the chimney to attack the 'good guys', sucking their blood, whereas during the day the monsters are transformed into people who meet in the appropriately named house "The Red Maples" and plot a conspiracy against the independence of the Baltic States. Another of Puriņš’ novels, Mana dzìve jūsu rokās (My Life Is In Your Hands, 2002), tells the story of a teenager possessed by Satan, who is urged by the Devil to undertake various evil deeds and is released only when he falls from a church tower. However, the appearance and activities of the Devil, and of his wife Lilith, who infests the boy's stomach in the form of a snake, are described so naively and unconvincingly, using clichés seemingly borrowed from secondrate horror movies, that instead of the horror intended by the author, the effect is essentially comic. Much more effective horror episodes appear in Puriņš novel for teenagers, Zilā jumprava (The Blue Lady, 1990): 14-year-old Aigars, participant in an archaeological excavation, is pursued at night by an immense skeleton with a stone axe, because his bed has unintentionally been placed over an ancient burial site. Although, of course, this is only a dream, it is much more impressive than the satanic and vampire figures in Puriņš' later prose.

Jānis Ivars Stradiņš also employs mystical elements in his novel Dēmonu villa (Villa of the Demons, 1993) - a very unusual detective novel that combines stereotypes from horror literature as well as from various kinds of detective stories and from apocalyptic thrillers. A real conspiracy of the Devil's henchmen is plotted in a strange little house hidden away in a courtyard behind the high-rise buildings of Ģertrūdes Street in the city of Riga: it begins with the use of charmed 'ritual masks' to bring about the death of particular individuals and ends with plans for world domination. The novel includes overtones of supernatural horror (the masks), as well as passages where the emotional effect is more one of revulsion. (Stephen King, in Danse Macabre (2002), a discussion of the horror genre from the perspective of literary theory, describes this 
technique as the 'gross out', defining it as the most primitive method of creating a horror effect (King 2002: 17)). For example, there is an episode with hordes of cannibal rats that eat one of the heroes in a secret underground passageway, an account that does indeed produce a sense of 'gross out'. The author presents a generous array of banal clichés in his description of the evildoers and the atrocities they plan to commit. In such concentrated form they lose credibility and, as in the works of Puriņš, border on the farcical. At around this time, the critic Valdis Felsbergs expressed his conclusion in the magazine Karogs, with a pessimism that was perhaps quite well-founded:

We are doing rather badly in terms of the genre diversity of our local product. [...] One genre that requires a living person is horror literature. The terrifying dénouement can be realistic or it can venture into the realm of mystery, but there must be a living human being, someone the reader can identify with. After all, who's going to get carried away with someone else's horror? (Felsbergs 1995)

Precisely this 'human factor' is beyond the abilities of many recent authors, because it is impossible to empathise with a caricature, the threat to whose life is not altogether believable.

In his ironic stylisation, a "novel with a terrifying ending", and an equally 'original' title, Sakroplotō rēga drausmìgais lāsts (The Dreadful Curse of the Mutilated Ghost, 1997), Ėriks Kūlis plays with the most banal stereotypes of horror literature. The protagonists include a cemetery watchman living in the middle of the cemetery and regularly communicating with ghosts, the vampire Count Brūce ("Gash"), a howling ghost named Kampējs ("Snatcher"), the sadistic surgeon Skalpelis ("Scalpel"), engaged in illegal experiments, and similar characters. The parody of horror does, of course, have its place in literary culture, but as a work of Latvian literature, it has one disadvantage: there being so few original works in this genre, few translations and none at all that include all the clichés Külis plays with, let alone in such concentrated form, the parody lacks a 'point of reference' in the form of a seriously intended text, and becomes a hyperbolised caricature of a non-existent original. Moreover, the author has not managed to maintain the homogeneity of the plot even within the frame of the rules he sets himself:

$[. .$.$] it's been a long time since I read prose so crammed with corpses. There's$ continual murder, torture, disembowelment, dismemberment, burial alive or cannibalism. But we must ask: why do we experience an overwhelming attack 
A Cloud of Vapour, the Cool of the Cellar: the Horror Genre in Latvian Literature

of boredom when reading this little book? One reason is that the elements of the plot do not go together at all, but split and run off in every direction. [...] Particular episodes are connected not by the logic of the plot, but by the series of corpses. (Berelis 1997)

Accordingly, the characteristic elements of horror prose are present in the work, but do not achieve the desired effect.

In recent decades Viesture Reimers (pseudonym of writer and literary critic Guntis Berelis) has also made a contribution to the Latvian horror genre with four stories that include interpretations of classic themes and playful postmodern elements. It should be added that horror elements may also be found at the centre of several stories penned under Berelis' real name. "Mēs bijām l̦oti veci" ("We Were Very Old") and "Mēs esam no teātra" ("We're From the Theatre") (in the volume Minotaura medìbas (Hunting the Minotaur, 1999)) are only a couple of examples. The story "We Were Very Old" tells about a bunch of almost centenarian pensioners engaged in the systematic killing of 'public enemies', utilising firearms as well as bricks thrown from windows. In the story "We're From the Theatre" a troupe of actors engaged in fanatically realistic theatre dismember and eat the sole member of their audience. These can be seen as caustic metaphors, characteristic of Berelis, as postmodern techniques or simply as shock therapy, whereas in the stories written under the name Reimers and included in the same volume, the element of horror is always of supernatural origin and plays the main conceptual role. In the story "Vini ir" ("They Are") an eight-year-old boy takes his revenge on a psychotherapist by sending him the figures from his nightmares, which turn out to be all too real; in the story "Nakts vilciens" ("Night Train") the narrator's friend loses his life trying to investigate a ghost train on a stretch of track that has no beginning or end, while the story "Spogulis" ("The Mirror") plays on many people's age-old fear of this everyday object, proceeding from a slight sense of unease to a truly horrifying dénouement. The writer himself admits that the figure of Viesturs Reimers has been created specially for horror stories:

Reimers wrote horror stories. This genre has a kind of overwhelming allure; it is a beautiful game played simply for its own sake. All of the required elements have been defined by the ancients, who related dreadful tales by the campfire, and by children, who scare each other with stories of razor-blade nails and red people. Perhaps people have some kind of archetypal horror-storytelling nerve, which is rather hyperdeveloped in me - otherwise I can't see why making up horror stories should give such pleasure. (Berelis 2000: 26) 
This kind of double authorship for the purposes of different genres is unique in Latvian literature.

At least so far, two age-old archetypical figures of the horror genre, namely the vampire and the werewolf, have been rather unusually depicted in Latvian literature. To date, vampires have actively appeared in only two works: the thriller Vampire Conspiracy by Andris Puriņš, described above, where they have a political and symbolic role, and in the young adult fantasy novel Nepabeigtais skūpsts (Unfinished Kiss, 2011) by the young author Laura Dreiže, conspicuously influenced by American writer Stephanie Meyer's bestseller Twilight (2005). In both cases there is a romantic love story of human girl and a charming male vampire, but the destructive, bloodthirsty nature of the vampire population is not disguised either. Dreiže's work contains what is possibly the most carefully modelled vampire community in original Latvian literature, although it resides not in Latvia, but in an imaginary Central European town. The werewolf theme has been used by Jānis Mauliņš in the historical novel Pédas (Tracks, 1980 ), but in a figurative sense: a rebellious $17^{\text {th }}$-century Latvian peasant Toms, resisting his German lords, hides in a forest and exploits the prevailing superstition to make the lords and their servants believe that the forest is home to werewolves. We should also mention the volume of stories Kurzemes vilkaču nostāsti (Werewolf Tales of Kurzeme, 2007) by theologian Ralfs Kokins, which brings together an interesting body of folklore on these mythical beings.

One of the most recent original works with horror elements in the plot is the novel Naktstaurinšs (The Moth, 2012) by Laura Dreiže, which has no trace of reworked folklore characters or the projection of vague fears. Instead, the plot centres on a clinic set up by a crazy medical genius, where people endowed with supernatural abilities are studied by subjecting them to terrible torture, so that most of them die as a result of this 'research'. This medically-oriented horror is effective, suggesting analogies with real $20^{\text {th }}$-century phenomena.

We may conclude that Latvian literature does include motifs characteristic of the horror genre, but in these works horror is generally not the dominant element, which means that there are few pure examples of a genre in which one of the essential requirements is to scare the reader.

In conclusion we may mention an interesting phenomenon of recent Latvian literature: an unusual volume of contemporary children's horror folklore, namely Spoku stāsti (Ghost Stories, 1991, 1996), collected and arranged by writer Māris Rungulis, consisting of tales passed down by children from generation to generation by word of mouth, involving the stories about the Queen of Spades, the Red Piano, the Red Curtains etc., which on the one hand fulfil the true function of horror prose - achieving a catharsis through scaring the listeners and thus releasing them from fear - while on the other hand they 
A Cloud of Vapour, the Cool of the Cellar: the Horror Genre in Latvian Literature

often have a comic dénouement that helps the listener ${ }^{3}$ to ridicule their own fears. As pointed out by Guntis Berelis,

the ghost stories can also act as an 'antidote to fear' - as an unusual compensation mechanism to free oneself from potential fears. Accordingly, much more important than 'real' fear, in the form of words as signs, is the fear of anticipation, and accordingly the structure of these ghost stories is for the most part reminiscent of miniature novels: an introduction drawn out in an almost professional manner is followed by a sudden, abrupt dénouement, a momentary climax, which sets the whole course of events in an entirely different light. (Berelis 1992)

As these stories have been brought together and published, they form an unusual part of the still very sparsely represented body of works in the genre of horror.

Bearing in mind that similar versions of these stories have been circulating among children for at least a couple of decades, we may conclude that the tradition of horror stories, at least in oral folklore, is still as much alive as it was at the time when folklore researchers Ansis Lerhis-Puškaitis and Pēteris Šmits collected Latvian folk legends. Thus, there is reason to hope that eventually we will have a Stephen King of our own among Latvian writers.

\section{Bārbala Simsone \\ Ernestines 25-8 \\ LV-1046 Rìga \\ LATVIJA}

\section{References}

Berelis, G. 1992. Spoku stāsti. - Karogs, 2, https://berelis.wordpress.com/category/ recenzijas/spoku-stasti/ (06.02.2012.)

Berelis, G. 1997. Ēdienkartē - miroṇi un rēgi garlaicības mērcē. - Diena, 18.08, 10.

Berelis, G. 1999. Latviešu literatūras vēsture. Rīga: Zvaigzne ABC.

Berelis, G. 2000. Nezinu, kāpēc esmu Berelis. 11 dažādi spalvasbrāḷi. Rīga: Likten,stāsti. Brigadere, A. 1997. Dievs, daba darbs. Riga: Zvaigzne ABC.

3 These stories are traditionally told orally, sometimes accompanied with various theatrical elements. 
SIMSONE

Dibovska, J. 2008. Vladimirs Kaijaks. Stāsts „Visu rožu roze”. - http://www.satori.lv/ raksts/2442/Julija_Dibovska/Vladimirs_Kaijaks_Stasts_Visu_rozu_roze (22.02.2012).

Felsbergs, V. 1995. Par šausmu stāstiem un šausmīgiem stāstiem. - Karogs, 1, 136-144.

Grīns, A. 1990. Nameja atgriešanās. Nameja atgriešanās. Rīga: Zinātne.

Jakubāns, A. 1987. Par Vladimira Kaijaka „Visu rožu rozi”. - V. Kaijaks, Visu rožu roze, Rìga: Liesma, 185-189.

Kaijaks, V. 1973. Mēmais. Akācija akmens pagalmā. Rīga: Liesma.

Kaijaks, V. 1987. Visu rožu roze. Rìga: Liesma.

King, S. 2002. Danse Macabre. London: Time Warner Books.

Rainis, J. 1950. Spēlēju, dancoju. - Raksti, IX sēj. Rīga: Latvijas Valsts izdevniecība, 287-511.

Zariņš, K. 2000. Piemini nāvi, Heidenkranc! Savādi likteņi. Rīga: Zinātne. 